\title{
The conduct of subsidiarity checks of $E U$ legislative proposals by national parliaments: analysis, observations and practical recommendations
}

\section{Philipp Kiiver}

Published online: 10 November 2011

(C) The Author(s) 2011. This article is published with open access at Springerlink.com

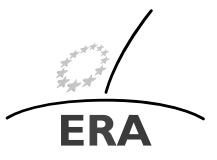

EUROPÄISCHE RECHTSAKADEMIE ACADEMY OF EUROPEAN LAW ACADEMIE DE DROIT EUROPEEN ACCADEMIA DI DIRITTO EUROPEO TRIER - TREVES - TREVIRI

\begin{abstract}
This paper provides a legal and empirical analysis of certain aspects of the European Union's early warning system for the principle of subsidiarity. It discusses the admissibility criteria for opinions from national parliaments against EU legislative proposals; it considers which principles national parliaments actually apply in these opinions in practice; and it develops practical legal techniques on how to incorporate principles other than subsidiarity in such opinions.
\end{abstract}

Keywords National parliaments · European Union · Subsidiarity

\section{Introduction}

Since the entry into force of the Treaty of Lisbon in 2009, the early warning system for the principle of proportionality is officially operational. National parliaments are invited to check EU legislative proposals against the principle of subsidiarity and to send a letter called reasoned opinion to the Brussels institutions if they believe that the principle is violated. ${ }^{1}$ Yet effectively the application of this subsidiarity check had started already well before its official entry into force. In 2006 the European

\footnotetext{
${ }^{1}$ The core provisions are Articles 6 and 7 of Protocol no. 2 TEU/TFEU. Articles 5 (3) and 12 (b) TEU and Article 69 TFEU also refer to that Protocol.

This article has been written in the context of a project financed through a Veni grant by the Netherlands Organisation for Scientific Research (NWO). It is based on a presentation given by the author at the ERA conference Subsidiarity Check which took place on 9-10 June in Trier.

Dr. P. Kiiver Associate Professor of European and Comparative Constitutional Law ( $\varangle)$ Public Law Department, Faculty of Law, Maastricht University, P.O. Box 616, 6200 MD, Maastricht, The Netherlands e-mail: philipp.kiiver@maastrichtuniversity.nl
} 
Commission has declared, in its Barroso initiative, to welcome letters from national parliaments as part of a broader political dialogue. ${ }^{2}$ And in fact the national parliaments, in their half-yearly inter-parliamentary conference COSAC, had decided already in late 2004 to select potentially interesting EU proposals and to experiment collectively with the subsidiarity check as it was enshrined, at the time, in the Constitutional Treaty. ${ }^{3}$ This means we have not just two but about seven years of practical experience. What lessons can we draw thus far? What goes well, what are the challenges? How do different parliaments, and chambers of parliaments, deal with their role under the subsidiarity check? This article shall review some of the most important procedural details of the system, with a focus on the admissibility of reasoned opinions; it shall then take stock of the most important experiences, focusing on the substantive scope of opinions in practice, and formulate policy recommendations for the future. But first, since the subsidiarity check is merely one of the European roles that national parliaments can and do play, a brief legal background shall be provided regarding the role of national parliaments pursuant to the EU Treaties in general.

\section{National parliaments in the European Treaties}

Traditionally, the parliaments of the Member States were not an object of particular interest for the system of the European Treaties. True, national parliaments were typically the ones who ratified these Treaties in the first place, who played an important role in calling to account national ministers as they negotiated directives in the Council, and who, in their legislative capacity, transposed directives into national law. However, none of these roles were created or regulated by the Treaties themselves: they derived, where applicable, from national constitutional law. Accordingly, these functions could, and still can, differ across Member States: referendums may replace parliamentary votes for Treaty ratification, the national government or regional lawmakers may replace the national parliament regarding the transposition of directives, and the means and intensity by which parliaments call to account their ministers in EU affairs is a matter of diverse legal and political idiosyncrasies in each system. ${ }^{4}$ Nevertheless, over the course of the 1990s the Treaties have been increasingly addressing national parliaments for various purposes: first in Final Act Declarations (Maastricht Treaty), then in a Protocol (Treaty of Amsterdam) and finally in the text proper (Constitutional Treaty and Treaty of Lisbon). In fact by now, under the regime of the Lisbon Treaty, the Treaties and Protocols of the EU explicitly mention the national parliaments on no less than two dozen occasions.

To appreciate the various instances where the TEU, the TFEU and their Protocols address the Member States' national parliaments for EU purposes, it is necessary to go through the entire text of these instruments, though. In other words, it is

\footnotetext{
2 ‘A citizens' agenda-Delivering results for Europe', COM (2006) 211 final.

${ }^{3}$ COSAC Secretariat, Report on the results of COSAC's Pilot project on the 3rd Railway Package to test the "Subsidiarity early warning mechanism", Luxembourg, 17-18 May 2005.

${ }^{4}$ Kiiver [7]; see also Tans [10]; Auel, Benz [1] and the still-influential volume Maurer, Wessels [9].
} 
not enough to check Article 12 TEU. That Article states: 'National Parliaments contribute actively to the good functioning of the Union:' and, after that colon, goes on to list a number of instances where either the TEU, the TFEU or the Protocols refer to national parliaments. However, several instances are actually not restated in Article 12 , without any obvious reason why not. For example, Article 12 affirms relatively banal rights, such as the right of national parliaments to be notified of incoming EU membership applications. But at the same time it omits rather significant facilities like the binding veto right of each national parliament against simplified Treaty amendment in the area of family law. The body of the Treaties and Protocols itself yields the following, far more helpful list:

\subsection{Information rights}

- The national parliaments' right to receive directly the Commission's consultative documents, the annual legislative programme as well as any other instrument of legislative planning or policy (Article 12 (a) TEU and Article 1 Protocol No. 1 TEU/TFEU);

- the right to receive directly EU draft legislative acts: from the Commission if it concerns Commission proposals, from the European Parliament if it concerns initiatives of the European Parliament, and from the Council if it concerns proposals from a group of Member States or requests or recommendations from the Court of Justice, the European Central Bank or the European Investment Bank (Article 12 (a) TEU and Article 2 Protocol No. 1 as well as Article 4 Protocol No. 2 TEU/TFEU);

- the right to receive amended drafts and legislative resolutions of the European Parliament and positions of the Council on draft legislative acts (Article 4 Protocol No. 2 TEU/TFEU);

- the right to receive directly the agendas for and the outcome of meetings of the Council (Article 5 Protocol No. 1 TEU/TFEU);

- the right to have special attention drawn to planned applications of the flexibility clause (Article 352 TFEU) in the context of the regular subsidiarity enforcement procedure of Protocol No. 2 TEU/TFEU;

- the right to be notified of planned applications of the ordinary Treaty revision procedure (Article 12 (d) and Article 48 (2) TEU);

- the right to be notified of planned applications of the general passerelle within the simplified Treaty revision procedure (Article 12 (d), Article 48 (7) TEU and Article 6 Protocol No. 1 TEU/TFEU);

- the right to be notified of planned applications of the special passerelle in the area of family law (Article 81 (3) TFEU);

- the right to be notified of the receipt of EU membership applications (Article 12 (e) TEU and Article 49 TEU);

- the right to receive an annual report from the Commission on the application of Article 5 TEU on the principles of conferral, subsidiarity and proportionality (Article 9 Protocol No. 2 TEU/TFEU); and

- the right to receive the annual report of the Court of Auditors (Article 7 Protocol No. 1 TEU/TFEU). 


\subsection{Provisions envisaging or implying an evaluation by national parliaments}

- The national parliaments' right to be informed of the content and results of evaluations of policies in the area of freedom, security and justice (Article 12 (c) TEU and Article 70 TFEU);

- involvement in the evaluations of the activities of Eurojust (Article 12 (c) TEU and Article 85 (1) TFEU) pursuant to regulations to be adopted on Eurojust's structure, operation, field of action and tasks;

- involvement in the political monitoring or scrutiny of Europol (Article 12 (c) TEU and Article 88 (2) TFEU) pursuant to regulations to be adopted on Europol's structure, operation, field of action and tasks; and

- the right to be informed of the proceedings of the Council's standing committee on the operational cooperation on internal security (Article 71 TFEU).

\subsection{Provisions envisaging or implying active input from national parliaments}

- The respect by the EU institutions of an eight-week period between the transmission of a draft legislative act and its placing on the Council's provisional agenda, during which no agreement may be reached; the respect of a ten-day period between the draft act's placing on the provisional agenda and the adoption of a position; and the duty for the Council in each case to justify exceptions in cases of urgency (Article 4 Protocol No. 1 TEU/TFEU). In the light of the first two recitals of the Preamble of Protocol No. 1, this minimum delay rule is meant as an opportunity for domestic parliamentary scrutiny and the expression of opinions on EU draft legislative acts;

- the enforcement of the principle of subsidiarity (Article 12 (b) TEU as well as Article 5 (3) TEU, and again Article 69 TFEU specifically for the area of freedom, security and justice, all referring to Protocol No. 2 TEU/TFEU). The Protocol in turn includes:

- an early warning system for the submission of reasoned opinions which in turn trigger certain consequences when certain thresholds are reached (Article 3 Protocol No. 1 and Article 6 and 7 of Protocol No. 2 TEU/TFEU); and

- the jurisdiction of the Court of Justice to hear annulment actions for alleged breaches of subsidiarity notified by Member States on behalf of national parliaments (Article 8 Protocol No. 2 TEU/TFEU);

- the participation of representatives of national parliaments in Treaty amendment Conventions within ordinary Treaty revision (Article 12 (d) and Article 48 (3) TEU);

- the right for each parliament to veto the application of the general passerelle within simplified Treaty revision (Article 12 (d) and Article 48 (7) TEU);

- the right for each parliament to veto the application of the special passerelle in the area of family law (Article 81 (3) TFEU); and

- inter-parliamentary cooperation in accordance with Protocol No. 1 TEU/TFEU (Article 12 (f) TEU). Protocol No. 1 TEU/TFEU in turn includes:

- the right for COSAC, an inter-parliamentary conference, to issue contributions, without however binding national parliaments or prejudging their positions (Article 10 Protocol No. 1 TEU/TFEU); and 
- the task for COSAC to promote the exchange of information and best practice between national parliaments and the European Parliament (Article 10 Protocol No. 1 TEU/TFEU).

\subsection{Provision of dubious legal value}

- 'Member States are represented in the European Council by their Heads of State or Government and in the Council by their governments, themselves democratically accountable either to their national Parliaments, or to their citizens' (Article 10 (2) TEU, second clause). It is hard to see anything but a declaratory statement in that provision, which means it might as well have been put into a preamble. It could not be prescriptive since, for example, governments in parliamentary systems tend to be accountable only to lower chambers of parliament, not to senates, a nuance that Article 10 TEU does not capture; in any event, parliamentary accountability in the Member States predates Article 10 and can well continue to exist without it.

\section{The subsidiarity check: the procedural framework}

Behind a relatively straightforward idea of the subsidiarity check system, the innovation which tends to draw most attention as regards the role of national parliaments under the Treaty of Lisbon, looms a system of great complexity. The system is not just a loose exchange of opinions between national parliaments and Brussels, but a legally formalized communication framework with rights and obligations, admissibility criteria and deadlines. ${ }^{5}$ Article 6 of Protocol no. 2 to the TEU and the TFEU on the application of the principles of subsidiarity and proportionality in fact contains five admissibility criteria for reasoned opinions. Thus, a reasoned opinion must:

- originate in a national parliament or chamber thereof;

- concern a draft legislative act of the EU;

- be sent in time;

- contain reasons; and

- allege a violation of the principle of subsidiarity.

To start with the first criterion, the Treaties contain neither a definition nor a list of the institutions that are actually meant by 'national parliaments'. In most cases the question is not problematic, but there are grey areas. Can a regional parliament under certain circumstances be considered to be a (chamber of a) national parliament and, as a result, enjoy rights attributed to national parliaments proper? ${ }^{6}$ Or is a parliament or chamber allowed to issue reasoned opinions by a minority vote? What is undisputed is that a parliament or chamber can allow a committee to speak on its behalf, even without plenary endorsement, as long as the committee's opinion can be considered to represent the opinion of the parliament or chamber as a whole. I furthermore

\footnotetext{
${ }^{5}$ For an elaborate discussion on the procedure, its theory and practice, see Kiiver [5]. See also Cooper [3]; Louis [8], 429-452; Barrett [2]; and Wyrzykowski, Puchta \& Ziolkowski [11].

${ }^{6}$ This question acutely concerns Belgium, where regional and community assemblies are considered to form part of a composite national parliament together with the national parliament proper.
} 
submit that minority-based opinions must be accepted by the Union if a parliament or chamber were to decide to introduce such an instrument, as long as that opinion is, again, the uniform standpoint of the chamber as a whole. Similar constructions already exist in Member States such as Germany and France, where a parliamentary minority can trigger the launch of an annulment action against existing EU legislation before the Court of Justice. ${ }^{7}$ As far as the subsidiarity check is concerned, the Union is in no position to regulate parliaments' internal procedures, it cannot regulate whether they adopt their decisions by relative, absolute or qualified majority, of component members, of members present or of votes cast. And where a parliament or chamber as a whole is compelled to act, in accordance with the constitution, with legislation or the parliamentary rules of procedure, upon the motion of, for example, one-third of its members, the resulting reasoned opinion should be deemed admissible.

Reasoned opinions must refer to a draft legislative act, i.e. an act within the meaning of Article 3 of the Protocol. This is broader than it seems, but in a certain sense it is also narrower than it seems. It is broader because not only Commission proposals are covered but also initiatives of a group of Member States and the European Parliament as well as requests from the Court of Justice and the European Investment Bank and recommendations from the European Central Bank for the adoption of a legislative act. And it is narrower because a number of acts do not fall within the scope of the Protocol: the Commission's consultation documents within the meaning of Article 1 of Protocol no. 1 TEU/TFEU on the role of national parliaments in the EU, i.e. green and white papers and communications, but also 'amended drafts' within the meaning of Article 4 of Protocol no. 2. Even if the Commission, prompted by the subsidiarity check, amends its proposal—which so far has never happened-then that amended draft is not the object of another subsidiarity check. The same holds true for amendments adopted by the European Parliament and the Council. In other words, the subsidiarity check takes place neither at the beginning nor at the end of a legislative process, but in the middle of it. A national parliament that wishes to get involved earlier, and to follow up on what happens to its reasoned opinion and the draft, which may undergo heavy amendments, therefore must seek alternative information channels.

Incidentally, the Commission is committed, in the framework of the political dialogue, to reply to all letters from national parliaments even if they fall outside the scope of the subsidiarity check. ${ }^{8}$ This concerns letters in cases where the official yellow and orange card thresholds have not been reached, i.e. where, after the counting

\footnotetext{
${ }^{7}$ See Article 88-6 of the French and Article 23 (1a) of the German Constitution. Although many practitioners seem to assume that Article 8 of Protocol no. 2 gives national parliaments the right to initiate cases, or at least obliges Member States to create facilities for such initiatives, I should stress that at close reading Article 8, with its cumbersome passive grammatical construction, in fact creates neither rights for parliaments nor duties for governments, and that it merely repeats what is already known from Article 263 TFEU.

${ }^{8}$ See the Commission's message to the national parliaments: Practical arrangements for the operation of the subsidiarity control mechanism under protocol no 2 of the Treaty of Lisbon, letter of President Barroso and Vice-president Wallström of 1 December 2009, Annex, available at ec.europa.eu/dgs/ secretariat_general/relations/relations_other/npo/docs/letter_en.pdf.
} 
of letters and their conversion into votes, not enough votes have been raised against a proposal in order to force its review and re-justification. It also concerns letters which are not related to subsidiarity, of which more below. But it also concerns letters sent too early, e.g. letters responding to white papers and not to actual proposals, and letters sent too late, i.e. letters sent after the eight-week deadline or letters discussing legislation in force. The subsidiarity check is therefore narrower than the political dialogue in terms of both substantive scope and timeframe.

Speaking of timeframes: when is a national parliament's reasoned opinion considered to be 'in time'? The short answer is that the relevant period is eight weeks, but for practitioners' purposes this is in fact too general. The period can be both shorter and longer than that. It can be longer because the clock only starts ticking when the last language version of an EU proposal has been transmitted. ${ }^{9}$ Some versions are ready sooner than others, and the difference can amount to several weeks. When a parliament receives 'its' version, this therefore does not mean that the clock is already ticking; if a parliament, its committees, its members or staff are prepared to read a proposal in another language, notably English or French, even more time is gained. Furthermore, upon a COSAC initiative, the Commission does not count the month of August towards the eight-week total. The Commission likes to present this as a concession to take into account parliaments' summer recess, ${ }^{10}$ but of course it has a summer recess in August itself. It should be noted, though, that this arrangement only applies to the Commission and not the other initiators of legislative drafts, such as Member States, and it does not apply to other periods when a national parliament cannot be active either, such as the Christmas recess or the period after a dissolution of parliament pending elections or a re-constitution of the plenary. Yet the period may also be shorter. Article 6 of Protocol no. 2 does not contain any urgency procedures, but Article 4 of Protocol no. 1 does, in that the eight-week period during which the Council must wait for national parliamentary scrutiny can be overridden. Effectively, in such case the subsidiarity check is over. Parliaments who feel unjustly deprived of their opportunity to formulate a reasoned opinion, or parties otherwise seeking to challenge adopted EU legislation in court, are free to complain about the urgency override as well. For the cutting short of the period under Protocol no. 1 reasons must be given, and if those reasons are missing or insufficient, one may legitimately claim not only a breach of that Protocol but also a procedural violation of subsidiarity compliance.

A reasoned opinion must contain reasons, a blank rejection is not permissible but this does not actually occur in reality. What is more pertinent is what exactly is meant by subsidiarity. In principle, subsidiarity is neatly defined in Article 5 (3) TEU, but in practice different parliaments use different definitions of that term and, overall, seem to require a somewhat broader interpretation.

\footnotetext{
${ }^{9}$ Article 6 Protocol no. 2 TEU/TFEU. A small detail: the English version contains a superfluous comma after the word 'act', suggesting the opposite of what it supposedly means, namely that the clock starts ticking for each parliament individually and that parliaments are merely free to write their reasoned opinions in the Union's official languages. Evidently this is nonsense, and the punctuation in the French version is correct. Treaty and corrigendum drafters, please remove the extra comma from the English version!

${ }^{10}$ See note 7 above.
} 
Table 1 Typical wordings in reasoned opinions

\begin{tabular}{ll}
\hline Nature of the reasoned opinion & Formulation \\
\hline positive & Finds that subsidiarity has been complied with \\
& $\begin{array}{l}\text { Is unable to detect any breach of subsidiarity } \\
\text { Has no reason to make any comments }\end{array}$ \\
\hline negative & Has some doubts, concerns or reservations \\
& Requires further information, withholds verdict \\
& Finds that subsidiarity has been breached
\end{tabular}

\section{Form and scope of reasoned opinions}

Regarding the content of reasoned opinions, this article shall consider two key questions. The first is in which manner reasoned opinions are formulated by different parliaments in practice. The second is which principles are discussed therein, or from which angle parliaments approach their subject. The Commission makes incoming reasoned opinions available in a useful but hard to find online archive, and is busy adding documents received earlier as well. ${ }^{11}$

\subsection{Form}

Many national parliaments are apparently reluctant to categorically claim a violation of the principle of subsidiarity. The following types of formulations occur in practice (Table 1).

On the one hand, this raises the question whether reasoned opinions may be positive in the first place? Article 6 of Protocol no. 2 only envisages negative opinions alleging a breach. Nevertheless some parliaments also send positive verdicts: when they participate in collective review of a proposal selected by COSAC and find no breach, but also when they have considered a proposal upon their own initiative. The legal answer, I submit, is that 'reasoned opinion' is a substantive, not a formal concept. It will count as a vote even if it is not called a reasoned opinion, and it will not count as a vote even if it is called a reasoned opinion but is in fact positive. Calls for greater terminological clarity are understandable but ultimately a matter of political choice.

On the other hand, the question remains when exactly a reasoned opinion can be considered negative? Just how negatively do they have to be formulated? Here, as with other as yet unclear aspects of the subsidiarity check, the Commission prefers not to determine its standpoint, and instead observes how practice evolves and waits with a formal counting and weighing of reasoned opinions until the parliaments will start getting numerically closer to the yellow card threshold of one-quarter or onethird of the votes allocated to them. The COSAC secretariat in any event plays it safe: in the collective reviews COSAC has sponsored, of which there have been eight so far,

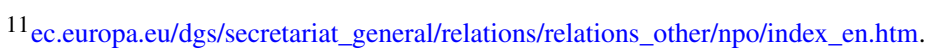


it counts a letter as a vote only where a parliament or chamber literally and unequivocally states that subsidiarity has been breached. Subtler opinions are not counted, but it does make a difference. It is often claimed that the yellow card threshold has never been reached yet. With a somewhat broader approach to counting opinions, however, it appears that there has been one case where the yellow card was raised, at least could have been deemed to have been raised. This concerns a proposal on the law of succession which had been subjected to a COSAC review in late 2009. ${ }^{12}$ The secretariat counted only one vote, the one of the Belgian Senate. But if it had also counted those parliaments which had said more or less the same as the Senate but which had formulated their objections in a more cautious way, and those which had said the same thing but which had framed it as a proportionality argument, as a competence issue or as a substantive comment, or which had claimed that the Commission's justification did not suffice to establish that subsidiarity was respected, then together the national parliaments would have generated between them around 20 votes. This is enough for a yellow card.

\subsection{Scope}

The scope of reasoned opinions can be as important as their form, which brings us to the second question: which principles are relevant for the subsidiarity check? Strictly speaking, the check revolves exclusively around subsidiarity: the Protocol relates to both subsidiarity and proportionality, but reasoned opinions may only allege breaches of subsidiarity. The principle of legality, i.e. the requirement of a competence-conferring legal basis for EU action, is not even mentioned there. Nevertheless, it is evident that all of these review criteria are relevant to parliaments conducting the check. In other words: based on the wording of their reasoned opinions, parliaments have a need for a somewhat broader scope of the subsidiarity check. This includes, for instance, a discussion of the necessity for EU action, as often it is claimed that a usual international agreement between the Member States is preferable to an EU measure or that such an international agreement already exists and works well. In addition to substantive objections, a routinely voiced criticism points to an alleged lack or insufficiency of the necessary justification of EU proposals. This may then violate the heavier burden of justification as it results from Article 5 of Protocol no. 2 , or constitute a procedural breach of the subsidiarity principle.

To illustrate divergent approaches, we may consider the example of the oft-cited proposal on the rights of seasonal workers from third countries in the EU. ${ }^{13}$ The two chambers of the Dutch parliament claimed that the Commission had failed to justify the added value of the proposal, notably because labour market conditions were said to vary across Member States and regions and because existing international collaboration was deemed sufficient. The chambers of the Czech parliament phrased

\footnotetext{
${ }^{12} \mathrm{COM}$ (2009) 154 final, see also the report: COSAC Secretariat, Report on the Results of the Subsidiarity Check on the Commission Proposal for a Regulation of the European Parliament and of the Council on jurisdiction, applicable law, recognition and enforcement of decisions and authentic instruments in matters of succession and the creation of a European Certificate of Succession, Madrid, May 2010, available at cosac.eu.

${ }^{13} \mathrm{COM}(2010) 379$ final.
} 
this on narrower subsidiarity grounds: in their view neither existing provisions in the Member States were insufficient to reach the desired goal, nor did the proposed EU measure have sufficient added value. This closely corresponds with the two subsidiarity criteria as they are formulated in Article 5 (3) TEU. The Austrian Bundesrat mainly claimed that there were insufficient cross-border aspects in this matter since each Member State was itself responsible for its own seasonal workers and their equal treatment with its own nationals. The Latvian parliament alleged a breach of proportionality but, interestingly enough, no breach of subsidiarity, confirming that, among other things, inactivity on the part of the Union would even breach its Treaty obligations.

Another example of diverse approaches to subsidiarity control-and therefore, it shall be argued, of the need for a broader scope of the procedure-is the equally oftcited CCCTB proposal on a common consolidated corporate tax base. ${ }^{14}$ The Swedish parliament noted that differences between tax systems are exactly a sign of healthy regulatory competition between economies and moreover reflected the preferences of the respective communities - a textbook example of a pure, almost purist subsidiarity argument. The Dutch lower chamber primarily focused, in a perhaps less pure manner, on the prospect that some Member States may lose out as others gain advantages from the proposed system, and that the measure would breach the Member States' tax sovereignty. The UK Commons considered subsidiarity breached above all because they found the Commission's justification to the contrary less than compelling.

It may be noted as a matter of general observation that some parliaments feel more bound by the scope of subsidiarity than others. Some chambers pay little attention to the limits of subsidiarity review. The chambers of the Dutch parliament, by contrast, whether they send joint or separate opinions, seek to formulate their opinions as much as possible as subsidiarity arguments, and even where they discuss legality or proportionality, this is still neatly separated through different headings. The result is a relatively formal review style, which may be likened to advisory opinions from a Council of State where it checks whether a bill complies with the constitution. ${ }^{15}$ Practitioners point out that this resulted at the early stages from the fact that civil servants would draw up draft opinions, whereas these opinions have become more political as of late. ${ }^{16}$ And still Dutch opinions are in no way comparable to the unabashedly political views expressed by the UK House of Lords, or to the letters from the German Bundesrat which routinely proposes detailed amendments to virtually every article in an EU draft legislative act, including the mentioned seasonal workers proposal. The Dutch parliament may, regarding its style of reasoned opinions, be rather grouped together with the Greek parliament, the Austrian Bundesrat and the French Senate. Undoubtedly they are all driven by political incentives-otherwise no politician would invest time and energy into the writing of letters-but here one seeks to implement the task in a sober and subsidiarity-oriented way. Either because one is aware of the risk that otherwise at some point opinions will not be counted as votes, or

\footnotetext{
${ }^{14}$ COM (2011) 121 final. This proposal has been prominently discussed at an ERA seminar on the practical implementation of the subsidiarity check held at Trier in June 2011.

${ }^{15}$ See Kiiver [6].

${ }^{16}$ Kester, van Keulen [4].
} 
because one simply wishes to stick to the letter of the Treaties; perhaps because the relatively calm subsidiarity check allows mainstream politicians to complain about EU proposals without coming across as Eurosceptics. Or because of a combination of several factors.

\section{Recommendations}

It is hoped that scholarship can make a contribution to practice through a thorough legal analysis of procedural rules on the subsidiarity check and a calm comparative reflection on its use. The result is in this case a set of recommendations for members of national parliaments and also, perhaps even primarily, parliamentary staff involved in the drafting of reasoned opinions.

The main recommendation is to phrase possible objections to EU measures as far as possible in the form of subsidiarity arguments, even if they have only partly to do with subsidiarity proper, and to indicate explicitly and clearly that the respective letter is a reasoned opinion in the sense of Protocol no. 2 alleging a breach of the subsidiarity principle in the sense of Article 5 TEU. One often sees opinions which do not explicitly discuss subsidiarity or which do not clearly claim a breach. The risk is that the Commission will consider the letter as input to the political dialogue, outside the subsidiarity check, and reply to it individually. In contrast with a triggered yellow card, the news value of such an event for the media is relatively low. Let us be honest: even though to an academic the subsidiarity check may most closely resemble an advisory procedure, ${ }^{17}$ or a dialogue rather than co-legislative bargaining, ${ }^{18}$ to politicians it is still highly interesting whether they can actually stop undesired legislation or not. If this is the case, then it is advisable to play by the rules.

What if a complaint does not directly relate to subsidiarity? It is usually a shame to see an objection of this sort vanish into the political dialogue. But there are possibilities to adopt a somewhat broader interpretation of the subsidiarity check without breaching the letter of the Protocol. First, it is absolutely legitimate to declare an insufficient justification a procedural breach of the principle of subsidiarity, in particular of Article 5 of the Protocol. National parliaments are not expected to supply justifications for EU measures of their own, but to verify whether proposals violate the subsidiarity principle in accordance with Protocol no. 2, which after all includes the initiators' duty to justify. Second, also legality or competence can be brought under the subsidiarity check. Without competence the Union is unable to achieve its aims better than the Member States, so that without competence a subsidiarity verdict can never be positive. An absence of competence for the EU, and even a partial encroachment upon Member States' competences by one of a proposal's provisions, is a legitimate ground for a reasoned opinion. This is true, for example, where an internal-market directive threatens to unlawfully regulate an aspect of family law, substantive criminal law or tax law of the Member States. Third, even under a subsidiarity heading a proposal can go 'too far'. This does not exclusively have to be a

\footnotetext{
${ }^{17}$ See note 15 above.

${ }^{18}$ Cooper [3], pp. 281-304.
} 
matter of proportionality and thus be ignored. For even under subsidiarity a certain gradation is conceivable. There may be enough subsidiarity-based legitimacy for, say, an EU recommendation - because the Union has a better overview of diverse laws in the Member States than the individual Member States themselves-but this does not mean that there is automatically enough subsidiarity for any type of EU action. Subsidiarity may run out, as it were, when it comes to total harmonization. In other words, subsidiarity is not a binary principle for certain policy sectors but must be applied to proposals, and provisions within proposals, on a case-by-case basis. This may also be reflected in reasoned opinions.

Finally, a small recommendation is in order. It does not seem advisable to claim as a national parliament that a subject should be dealt with via an international agreement instead of through an EU measure. Some parliaments state this occasionally. It is surely legitimate to argue that an already existing international agreement- the ILO in the case of seasonal workers, the ECHR in the case of suspects' right to an interpreter in criminal proceedings-makes EU action superfluous, or that the global dimension of a problem makes even EU action inadequate so that it will not produce better results than individual national action. But the argument that an agreement yet to be concluded is a better or more effective alternative to an EU measure is implausible and in fact dangerous from the parliament's own point of view. After all, the parliament thereby concedes that there is a problem that requires a cross-border approach, which is in fact one of the classical cases where subsidiarity justifies transnational measures. Furthermore, subsidiarity is not concerned with the choice between EU and non-EU international regulation. Those who argue in favour of international agreements will thus potentially fail to score any votes in the subsidiarity check and, in fact, will only strengthen the Commission's hand by admitting the existence of a transnational problem.

\section{Conclusion}

Many views are possible on the nature and meaning of the subsidiarity check by national parliaments in the EU. For some the system is fine as it is, whether they mean it honestly or cynically because they do not want it to be any stronger; for others, the mechanism is not powerful enough. In either case it is advisable to recognize the procedure for what it is: it is not simply a loose exchange of opinions, but a communication framework that is subject to legally defined procedural rules, including admissibility criteria and deadlines. Regarding the form and scope of reasoned opinions, the national parliaments are still largely experimenting: they compare each other's letters and observe that different styles are possible, and the Commission is, for now, not too strict in assessing the admissibility of such letters, certainly where the numbers are still a long way from reaching the official thresholds. But some recommendations are possible already now. It is certainly the safest option for a parliament to phrase objections as subsidiarity arguments, and it is possible to thereby include considerations which are also related to adjacent principles, notably competence, proportionality and the duty to justify. This article sought to bring those adjacent principles within the scope of the subsidiarity check, thereby accommodating national parliaments' evident need for a broader scope, without violating the letter of the Treaties. If national 
parliaments use this scope, they are also advised to seize the potential media value of a triggered yellow card: those who harbour objections should not be too subtle in expressing them as mere worries or reservations. A proper reasoned opinion should contain, in the very beginning, a standard formula that makes clear that this is in fact a reasoned opinion alleging a breach of the principle of subsidiarity within the meaning of Article 5 TEU and Protocol no. 2. A more nuanced reasoning may still follow afterwards.

Open Access This article is distributed under the terms of the Creative Commons Attribution Noncommercial License which permits any noncommercial use, distribution, and reproduction in any medium, provided the original author(s) and source are credited.

\section{References}

1. Auel, K., Benz, A. (eds.): The Europeanisation of Parliamentary Democracy. Routledge, London (2006)

2. Barrett, G.: Introduction. In: Barrett, G. (ed.) National Parliaments and the European Union: The Constitutional Challenge for the Oireachtas and Other Member State Legislatures. Clarus, Dublin (2008)

3. Cooper, I.: The watchdogs of subsidiarity: national parliaments and the logic of arguing in the EU. J. Common Market Stud. 44, 281-304 (2006)

4. Kester, J., van Keulen, M.: De Tweede Kamermethode: versterkte parlementaire invloed op Europese besluitvorming, RegelMaat 26 (2001) (forthcoming)

5. Kiiver, Ph.: The Early Warning System for the Principle of Subsidiarity: Constitutional Theory and Empirical Reality. Routledge, London (2012)

6. Kiiver, $\mathrm{Ph}$.: The early warning system for the principle of subsidiarity: the National Parliament as a Conseil d'Etat for Europe. Eur. Law Rev. 36, 98-108 (2011)

7. Kiiver, Ph.: The National Parliaments in the European Union-A Critical View on EU ConstitutionBuilding. Kluwer Law International, The Hague/London/New York (2006)

8. Louis, J.-V.: National parliaments and the principle of subsidiarity: legal options and practical limits. Eur. Const. Law Rev. 4, 429-452 (2008)

9. Maurer, A., Wessels, W. (eds.): National Parliaments on their Ways to Europe: Losers or Latecomers? Nomos, Baden-Baden (2001)

10. Tans, O., et al. (eds.): National Parliaments and European Democracy; A Bottom-up Approach to European Constitutionalism. Groningen, Europa Law (2007)

11. Wyrzykowski, M., Puchta, R., Ziolkowski, M.: The role of national parliaments in the European Union (General Report). In: Rodriguez Iglesias, G.C., Ortiz Blanco, L. (eds.) The Role of National Parliaments in the European Union-Proceedings of the XXIV FIDE Congress, Madrid, 2010, vol. 1. Servicio de publicaciones de la Facultad de Derecho Universidad Complutense, Madrid (2010) 